\title{
New Approaches to National Economic Accounting in Developing Countries with a Large Foreign Trade Sector
}

\section{Kari Levitt}

This paper is based on the system of national economic accounts for Trinidad and Tobago which was designed by the author in the hope that it might eventually serve as a standard system of national and regional 1 economic accounting for the countries of the Commonwealth Caribbean. Here we confine the discussion to a critique of the 'Old'2 and ' $\mathrm{New}^{3}$ United Nations Systems from the point of view of their limited usefulness for economic analysis and planning in countries dominated by the operations of transnational enterprises-whether in their export or industrial sectors, or, as is indeed normal, in both. We subsequently outline some of the features of the system of national economic accounts designed for Trinidad and Tobago, with emphasis on non-technical aspects. ${ }^{4}$

It is self evident that the policy problems-and therefore also the data requirements-of small, open and dependent economies are different from those of the large developed metropolitan countries whose statistical practices have largely shaped the United Nations Systems of National Accounts. In view of recent dramatic changes in the world prices of key export and import commodities, and the (belated) recognition of the impact of the operations of transnational enterprises on developing countries with an important foreign trade sector, it is more relevant than ever to create systems and procedures of national economic accounting which can trace the effects of exogenous changes on internal economic omission structure of production, consumption and capital formation to the structure of income and employment generation; to sources and use of foreign exchange; to the revenues and expenditures of government; and also to the structure of financial flows.

1 In the context of this discussion the region is comprised of the countries of the Commonwealth Caribbean.

2 United Nations: A System of National Accounts: Studies in Methods Series F, No. 2, 1951, commonly referred to as the Old SNA.

3 United Nations: A System of National Accounts: Studies in Methods, Series F, No. 2, Rev 3, 1968, commonly re ferred to as the New SNA.

4 For a detailed description of the accounting framework underlying the system, including the relationship between the Input-Output and the Seers-Type Matrices, as also for the actual industrial and trade classification used see Kari Levitt, 'New Approaches to National Economic Accounts in a Caribbean Context', a paper presented to the Accounts in a Caribbean Context, a paper presented to the
Sixth Conference of Caribbean Commonwealth Government Statisticians, Nassau, Bahamas, November 27 th to Deoember 5th 1974. (mimeo)
In recent years it has been widely acknowledged that global aggregates such as GDP and GNP are neither very meaningful as measures of economic welfare nor of much use to policy makers. My argument here is that national accounts of the usual product-expenditure variety are also of limited usefulness in quantifying the relationships described above, even where augmented by the occasional input-output table. They do not provide a satisfactory means of evaluating the benefits accruing to the set of transnational corporations on the one hand, and the national economy of the country in which they are operating, on the other. They do not enable even the crudest connections to be made between real transactions and their financing at the sectoral level, except perhaps in the case of the government sector. Typically the domestic capital market is fragmented, and the savings of some sectors are not available to finance capital formation in other sectors: this is hidden behind the fiction of a national savings-investment, or capitalfinance account.

Moreover, the conventional national accounts are untestably inaccurate precisely because they are too rough and global. What is really required is a systematic, detailed and reliable quantification of the inter-relations of the major sectors of the economy, especially by types of institution, so that, for example, the transactions of the set of non-resident-controlled enterprises can be monitored. One may wish to present the current and capital accounts of key non-resident controlled enterprises operating in the mineral/ export or agricultural sector in terms of their generation of foreign and local value added, classified by type of income, and their contribution to government revenue, foreign exchange earnings and uses, employment, creation and destruction of employment, etc. Furthermore, one may want to know the degree to which these firms draw on local finance for their capital expansion, etc. Such a system can provide a quantification of the direct and indirect costs and benefits of fiscal and other (protective) incentives normally extended to the non-resident controlled firms operating in the import-substitution sectors.

On the commonsense principle that it is possible to transform a large data set of reliable but incomplete information into a more compact 
system by the use of intelligent estimation and aggregation, whereas it is impossible to deduce reliable sectoral detail from rougher global national accounts, it follows that the development of an internally consistent data framework which can receive and code detailed data of a type and kind normally available in economies with large trade sectors and foreign companies, without destroying and thus wasting information, should be the starting point of the construction of an efficient system of national economic accounting.

Such a system assumes that one is operating at the frontiers of the technology of national accounting, where systems are designed for multiple classification of data inputs made possible by electronic data processing. There is no legitimate reason why third world countries should follow procedures, in national accounting or in any other area of administration, which were originally designed for the requirements of large metropolitan countries and should, moreover, follow them at the level of their most outdated practises. The argument here is that the approach should be the reverse: to design systems which are tailored to the needs and to the data of the country, using the most effective technical aids, including computerized data systems, and the most competent professional staff-precisely the people who all too often are the carriers of the reverse flow of technology from developing to developed countries.

Of course it has been asked whether a small country is justified in allocating professional resources of economists and statisticians to the development of a research and policy oriented system of national economic accounting considerably more sophisticated and detailed than many currently in use in the major metropolitan countries.

In response, I would argue that a small country dealing with a large complex of metropolitanbased enterprise needs to mobilize all its available professional resources to redress the unfavourable balance of information, and thus to protect its pecple from external exploitation. An effective, modern and efficient system of national economic accountability is more essential to governments of small third world countries than it is to those of richer metropolitan countries. Moreover, precisely because professional and financial resources are scarce, and because the degree of governmental intervention and participation in economic activity is and should be greater, the need for constructing a system which can monitor the transactions of all large private and public enterprises is crucial.
It is, incidentally, implicit here that the regulations protecting the confidentiality of the affairs of respondents must also be re-examined. Their rationale, which is the protection of the businessman with respect to his competitor is sound and operational with respect to individuals and small businesses, but not where one or a few enterprises are operating in key sectors-whether private or public. Indeed, if the rules of confidentiality developed in large metropolitan countries were to be mechanically transferred to much smaller countries with typically fragmented and incomplete industrial structures, as all too often is the case, the compilation of sectoral accounts would probably be in violation of Statistics Acts. There is really no justification for procedures which protect large enterprises against full disclosure of current and capital transactions, given the underlying imbalance in the bargaining power of large transnational corporations and the economic agencies of small host country governments, given the fact that these corporations know more about their immediate competitors than any developing country's economic agencies are ever likely to, and given the further fact that these corporations are either exploiting the natural resources of the developing country or are selling in its protected markets (usually with additional fiscal concessions). Indeed, outmoded and disfunctional protection of large enterprises against disclosure, whether in the form of Statistics Acts or otherwise, is a self-imposed obstacle to the development of integrated sectoral accounts in developing countries which are dominated by large corporations.

\section{The United Nations Systems of National Accounts \\ Both the Old and the New Systems of National} Accounts draw heavily on the practices of the national statistical offices and research institutes of the industrialized metropolitan countries. They thus reflect the economic structures and administrative data sources of the countries whose national accounting practices have contributed most evidently to the United Nations Systems. These are, in fact, the United Kingdom, the United States and a few other European countries. Consequently the aspects of the national economy which are articulated are those which accord with the business, government and research requirements, and with the administrative data sources, of countries which generally share the following general characteristics:

1. A diversified structure of production; diversified exports which are sold in diversified 
markets relatively free from intergovernmental or corporate quotas or administered transfer prices.

2. A structure of imports from diversified sources consisting of more or less essential 'noncompetitive' agricultural and mineral products. Absence of deliberate policies of 'import substitution'.

3. A pattern of ownership of non-financial enterprises in which the transactions of foreigncontrolled subsidiaries (including direct investment) are not significant in relation to the national economy as a whole.

4. Indigenous banking and financial institutions and an integrated capital market for equity and bond issues, both private and governmental.

5. A fiscal system, including social insurance schemes, geared toward the direct taxation of personal and corporate income and its redistribution. Such a system produces relatively reliable administrative records on incomes.

6. Warfare-welfare type of Government expenditures. Government expenditure is geared towards fiscal redistribution, the provision of social services and armaments.

7. Emphasis in government policy on stabilization of employment and prices by manipulation of fiscal and monetary policy within an accepted structural economic framework.

In contradistinction, the economies of developing countries with large foreign trade sectors are characterized by:

1. A limited structure of production geared towards the exportation of one or several more or less crudely processed agricultural and mineral products, sold in markets generally controlled either by transnational enterprises or by machinery established under negotiated commodity agreements, or by both. Export prices tend to be arbitrary (transfer) prices.

2. A structure of imports biased towards the importation of a variety of consumer goods whether in final or intermediate form and a large range of construction materials and capital goods. Import prices tend to be arbitrary (transfer) prices and the analysis of imports is vital to policies of industrialization as: well as to the control of inflation and the protection of terms of trade by indexation.

3. Preponderance of large foreign-controlled corporations operating in the territorial and jurisdictional area of the country. The current and capital transactions of these enterprises contribute simultaneously to the 'domestic' (i.e. geographical) product of the country and the national product of the metropoles in which the companies are headquartered.

4. The absence of a national capital market or sometimes even of indigenous commercial banking institutions; the practice of intra-corporate self-financing by local subsidiaries of foreign companies; and financing by local borrowing of market-oriented import-substitution subsidiaries of foreign enterprises.

5. A neo-colonial fiscal structure heavily dependent on revenues from taxation of agricultural or mineral export production and on customs duties. Income tax data tend to be incomplete and unreliable, particularly with respect to incomes of own account enterprises and the corporate sectors. (In these countries trade statistics are the most comprehensive single source of administrative data concerning economic transactions and also the key source of 'commodity flow' tables).

6. Government budgets geared towards development expenditures. For this reason it is conceptually difficult to draw a meaningful line between current and capital expenditures of the public sector and important to relate government capital expenditure to the production sectors they are intended to assist.

7. Public sector borrowing, particularly externally, is more like an exercise in diplomacy than a commercial transaction; the external public debt and its servicing assumes far greater importance than in metropolitan economies.

Before deciding where and how to amend standard national income practices to suit the requirements of open dependent economies, it is useful to summarize the characteristics which these derive from their metropolitan origins. In particular we note that:

1. Economic constructs are drawn from the aggregate categories of 'macro economic' Keynesian income analysis such as Gross National Product, National Income, Consumption, Government Expenditure, Gross Business Capital Formation, Exports, Imports and Savings appropriate to a fully developed and internally integrated economy.

2. Emphasis is on the rapid estimation and for ward projection of short-term movements in these aggregates (geared to detect business cycle fluctuations) and on the separation of real from price effects by development of global deflators. (Identification of the effects of price movements in an open economy requires quite different techniques.) 
3. The income and expenditure approach is more convenient for making estimates, as opposed to the 'value added in production' approach, which yields structural perspectives of low priority.

4. The treatment of commodity imports places more emphasis on trading area of origin and commodity characteristics than on their functional use. This reflects the absence of policy concern with the structure of imports in general and 'import substitution' in particular.

5. Capital finance (savings and investment) accounts are aggregated on the assumption that savings generated in one sector of the economy are freely available to finance investments in another sector; a similar assumption is implicit with respect to the treatment of external income and capital transactions.

6. Statistical integration of national income estimates with input-output tables which are increasingly accepted as a useful auxiliary attachment, is difficult, as a result of the historical origins of national accounting practices, starting from aggregative national income and product accounts. $^{5}$

The familiar Old United Nations SNA, which is still in use in many countries, contains six interrelated accounts congruous with the institutional categories of households, government and the 'rest of the world'. They are drawn from the functional activity concepts of consumption, saving and investment, government taxing, spending and borrowing and, of course, exporting and importing. The system derives from the Keynesian theory of income determination and was essentially developed for a closed economy with policy focus on governmental efforts to regulate the level of employment, income and prices by fiscal and monetary policies. Its first significant use as a policy aid however, came in the context of how to mobilize the real resources of Britain for the war effort. Indeed, the first set of official national income estimates for the United Kingdom was published in 1941 as a White Paper entitled 'An Analysis of the Sources of War Finance and an Estimate of National Income and Expenditure, 1938-1940.6

\footnotetext{
5 Referring to the situation in the United States for example, Professor Leontief has commented that "incompatible data are useless data. How far from a tolerab!e, not to say, ideal state our present economic statistics are in this repect, can be judged from the fact that because of differences in classification, domestic output cannot be compared for many goods, with the corresponding export figure and import goods, with the corresponding export figure and import figures. An unreasonably high proportion of material and spent not on the collection of primary information but on a frustrating and wasteful struggle with incompatible definitions and incongruous classifications". W. W. Leontie "Theoretical Assumptions and Non-observed Facts', October, 1970 (mimeo)

$6 \mathrm{~A}$ detailed exposition and critique of the Old SNA is contained in my Interim Report on a New System, 1973.
}

The New SNA, published in 1968, is a less Keynesian and more eclectic data framework which has been influenced by a number of developments in national accounting, economic model building and data processing. Among these are the following:

-Emphasis on statistical integration of data and accounts.

-Input-output accounting and models; commodity supply-demand balances.

- Integration of net financial flows with income accounts by tracing changes in year-end stocks of financial assets and liabilities.

--Extension of institutional classification of transactors from the Keynesian categories of households, governments and the rest of the world to categories of productive transactors.

-Availability of data processing facilities (computerization) capable of storing, arranging and re-arranging large data sets.

We consider the New SNA a useful contribution to the techniques of national economic accounting: its most important contribution lies in its emphasis on flexibility and statistical integration.

The authors of the New United Nations SNA have selected certain transactors and transactions for further articulation and have correspondingly drawn up schemes and classifications: the particular classes of transactors and transactions selected for elaboration are partly appropriate and partly inappropriate. In particular:

(a) While open and dependent economies require a system of commodity supply and demand. balances which, furthermore, distinguish commodities originating in domestic production from those which are imported, it does not require the fully articulated input-output accounts of the New SNA.

(b) The classification of institutional sectors of the economy suggested for New SNA is not particularly relevant. Thus whereas we require special treatment of foreign-controlled enterprises, we. do not require the suggested distinction between corporate and quasicorporate enterprises and private non-profit institutions.

(c) While the New United Nations System demands very great detail concerning production relations, it calls for a unique transformation of all incomes earned in production to consumption or accumulation. This is not meaningful for fractured and dependent economies. 
While the New SNA contains a chapter on the statistical problems and requirements of developing countries, the subjects selected for special treatment such as the distinction between the 'modern' and 'traditional' sectors, and the difference between the urban and rural areas, are not particularly appropriate to requirements in the Commonwealth Caribbean, while the serious and important accounting problems posed by foreigncontrolled companies practising transfer pricing on a country's exports and imports are not dealt with at all.

\section{New Approaches to National Economic Account- ing}

While it is undeniable that it is useful for purposes of international comparability to require countries to produce a minimal set of highly aggregated national accounts on a standardized basis, it is equally undeniable that, from the point of view of policy and planning requirements of developing countries, such standardization should not have very high priority. Furthermore, a system of national economic accounts such as has been designed for Trinidad and Tobago is characterized by flexibility and multiple classification so that it is not difficult to transpose the system into a standardized and aggregative one, for the convenience of international agencies.

By taking the most useful features of the Old and the New SNA, redefining industry classifications and institutional sectors, and arranging the detailed data inputs in an accounting framework originally devised by Dudley Seers $^{7}$ and elaborated by Best and Levitt, ${ }^{8}$ it is possible to devise a system which fits the following guidelines or criteria:

1. The need to quantify the structure of the economy, including the sectoral structure of production, exports, imports, consumption, ownership, capital formation, employment, and value of non-financial assets.

2. The need to provide sufficient detail to evaluate the effects of exogenous factors or public policies on income, employment, and foreign exchange earnings (and savings) which is, moreover, consistent with data availability.

\footnotetext{
7 Dudley Seers, 'An Accounting System for Projections In a Specialised Exporter of Primary Products.' (mimeo)

8 Best and Levitt, "An Ideal Type Accounting Framework to Plantation Economy Further Modified' and 'The National Capacity to Import' in 'Externally Propelled Growth and Industrialization, in the Caribbean', Centre for Developing Areas Studies, McGill University, 1968. (mimeo)

An Earlier version of these two papers is published in Second Conference of Caribbean Commonwealth Statisticians, Papers and Proceedings, Georgetown, 1967 and Conference on Devaluation, ISER, University of the West Indies, Mona, 1968.
}

3. The need to provide explicitly for the special role played by large foreign companies operating in the territorial and jurisdictional area of the country. The current and capital transactions of these companies are simultaneously part of the 'domestic' (i.e. geographical) economy of the host country and the national economies of the countries in which the parents and principals are located.

4. The need to integrate the current, capital and financial transactions of government and public enterprises into the system of accounts in such a manner as to yield maximum insight of the leverage of public policy on the total economy.

5. The desirability of building a statistical framework adapted to the 'commodity-flow' data available from trade statistics, and the need for a correspondence between sectoral employment data and all other sectoral economic data.

6. The objective of achieving internal accounting balances at the most disaggregated level consistent with data availability and resources of personnel.

7. The optional use of data processing facilities to achieve a sensible level of flexibility in the system of accounts.

8. The intelligent application of internationally recognised concepts and definitions to the particular requirements of the country. 